Gallagher, S. (in press). Philosophical antecedents to situated cognition. In Robbins, P. and Aydede, M. (eds). Cambridge Handbook of Situated Cognition. Cambridge: Cambridge University Press.

\title{
Philosophical Antecedents of Situated Cognition
}

\section{Shaun Gallagher}

In this chapter I plan to situate the concept of situated cognition within the framework of antecedent philosophical work. My intention, however, is not to provide a simple historical guide but to suggest that there are still some untapped resources in these past philosophers that may serve to enrich current accounts of situated cognition.

I will include embodied cognition as part of the concept of situated cognition. One often encounters these terms used together - embodied cognition and situated cognition - and it is clear that situated cognition cannot be disembodied, although some authors emphasize one over the other or provide principled distinctions between them. ${ }^{1}$ Philosophical thought experiments notwithstanding, however, the often-encountered brain in the vat, is, to say the least, in a very odd and artificial situation. Given what seems to be an essential connection between embodiment and situation, I will take the more inclusive and holistic route and view them accordingly.

The large landscape of sources for the concept of situated cognition is populated with important psychologists (from Vygotsky to Gibson) and biologists (from von Uexküll to Varela), many of whom have had a significant impact on how we think of cognition as complexly embodied and situated. ${ }^{2}$ I think that it is right to say that most contemporary philosophers who champion the idea of situated cognition have been positively influenced by this work in psychology and neurobiology. For the philosophers with whom we will be concerned, however, the psychology and biology of their time had less of a positive effect, and in some cases defined precisely what these philosophers were reacting against. What is even clearer is that these philosophers were reacting against a long philosophical tradition that

\footnotetext{
${ }^{1}$ Clark (1997) provides one of the best analyses of embodied and situated cognition. Anderson (2003), for example, provides the following principled distinction:

In my view, it is the centrality of the physical grounding project that differentiates research in embodied cognition from research in situated cognition, although it is obvious that these two research programs are complementary and closely related. . . Although related to and continuous with situated cognition, [embodied cognition] takes the physical grounding project as its central research focus. This project calls for detailing the myriad ways in which cognition depends upon - is grounded in - the physical characteristics, inherited abilities, practical activity, and environment of thinking agents. (pp. 92, 126)

For further discussion of this distinction, see Prinz (this volume).

${ }^{2}$ For a review of the psychological sources, see Clancey (this volume).
} 
simply ignored the importance of body and situation in favor of the isolated mind. This tradition included, of course, Descartes, but also Locke, Hume, and Kant, and almost every other modern philosopher one can name. To ignore embodiment and situation was the overwhelming tendency of the philosophical tradition up to and including many twentieth-century philosophers.

Before the twentieth century it is difficult, though not impossible, to find philosophers who could count as proponents of situated cognition. There is, however, a long tradition that emphasized practical reason, especially in discussions of ethics and politics, and in these discourses the idea of situated reasoning is not absent. One could mention here Aristotle's notion of phronesis (practical wisdom), which is a form of knowing or epistemic capacity that is highly dependent on the particular and practical (moral) situation in which it must be practiced. In the case of phronesis, one does not know in general, or by appeal to a set of rules, so much as one decides case by case - with special attention to the details of each case - what one must do. The Stoics also regarded the situation, defined in its most determined and concrete terms, as an important factor in knowing what one can and cannot do. These traditions, however, were not carried over into the realm of theoretical knowledge, or what philosophy has considered cognition per se (something closer to mathematics than to phronesis), which was most frequently thought to be independent of situation. Even moral deliberation was frequently modeled on context-free or mathematical thinking (think of Kant's categorical imperative or Bentham's utilitarian calculus). There may be a number of exceptions to this general view (I think Nietzsche would count as an exception, for example), ${ }^{3}$ but nothing like a fully developed concept of situated cognition is to be found prior to the twentieth century.

In general, then, if the roots of the idea of situated cognition extend back into the history of philosophy, they remained undeveloped and well covered by the ground from which the Enlightenment grew, not even to be unearthed in all the digging for epistemological foundations. But in the twentieth century this idea did break the surface, and it started to grow in certain philosophers who were reacting critically against the modern philosophies of Descartes, Kant, and numerous others. I focus on four such philosophers: Dewey, Heidegger, Merleau-Ponty, and Wittgenstein. These are four philosophers among a list that could include many others, such as William James, George Herbert Mead, Hans-Georg Gadamer, Aron Gurwitsch, Hans Jonas, Hubert Dreyfus, or more recently, Andy Clark, Mark

\footnotetext{
${ }^{3}$ If I say, "The mind thinks," Nietzsche (1967) responds in the following way:
}

If I say 'lightning flashes,' I have posited the flash once as an activity and a second time as a subject, and thus added to the event a being that is not one with the event but is rather fixed, is, and does not 'become.' - To regard an event as an 'effecting,' and this as being, that is the double error, of interpretation, of which we are guilty. (p. 289)

To conceive of the mind as a Cartesian thinking thing is to posit something over and above the situation in which thinking occurs. Thinking is not something that happens in a mind, as an attribute or quality that belongs to a subject who is isolated from the world; it is an activity or event in the world. 
Johnson (writing with George Lakoff), and Evan Thompson (writing with Francisco Varela).

\title{
Organism-environment
}

Situated cognition has become an important concept in educational theory, and one of the most frequently cited philosophers in this context is John Dewey (see, e.g., Bredo, 1994; Brown, Collins, \& Duguid, 1989; Clancey, 1997; Lave, 1988; Lave \& Wenger, 1991). Curiously, just as much as Dewey is cited in discussions of situated learning, he is almost entirely ignored in the philosophy-of-mind discussion of situated cognition. ${ }^{4}$ But Dewey was clearly the Dennett of his time, at least in terms of his enthusiasm for the science of mind and his rejection of Cartesianism. As early as 1884 Dewey reviewed the significance of the new physiological psychology, and he points to the importance of certain biological concepts of organism and environment:

\begin{abstract}
The influence of biological science in general upon psychology has been very great. . . . To biology is due the conception of organism. . . . In psychology this conception has led to the recognition of mental life as an organic unitary process developing according to the laws of all life, and not a theatre for the exhibition of independent autonomous faculties, or a rendezvous in which isolated, atomic sensations and ideas may gather, hold external converse, and then forever part. Along with this recognition of the solidarity of mental life has come that of the relation in which it stands to other lives organized in society. The idea of environment is a necessity to the idea of organism, and with the conception of environment comes the impossibility of considering psychical life as an individual, isolated thing developing in a vacuum. (Dewey, 1884, p. 280)
\end{abstract}

Dewey thus criticized conceptions of cognitive experience that construe it as narrowly individual, ideational, and passive. Experience is not something that happens in an isolated mind; rather, experience is biological, insofar as it involves an organism in an environment, and social, insofar as that environment is intersubjective. Cognition, then, emerges in the transactional relations that characterize organisms and the physical and social environment with which they engage. Experience is thus situated. "In actual experience, there is never any such isolated singular object or event; an object or event is always a special part, phase, or aspect, of an environing experienced world - a situation" (Dewey, 1938a, p. 67).

Dewey uses the notion of a problematic situation to describe how cognition involves coping with unfamiliar circumstances. Situations are problematic if there is some element of confusion, disturbance, uncertainty, or incompleteness that needs to be resolved and there is no clear direction that would lead to resolution. In such cases, cognition is a form of inquiry, and this is understood as a hands-on practical activity through which we transform the situation into one that is less confused and more comprehensible, and in which ideas for successful action start to emerge. An

\footnotetext{
${ }^{4}$ One clear exception to this is Johnson (2007), who borrows extensively from Dewey to support his conception of embodied, situated cognition.
} 
idea is not primarily an intellectual entity in the head but "an organic anticipation of what will happen when certain operations are executed under and with respect to observed conditions" (Dewey, 1938a, p. 109). Cognitive inquiry is not a purely mental phenomenon but involves an interaction between organism and environment to produce real changes in the causal couplings that characterize the situation. We should add the important point that the situation should be defined as inclusive of the inquirer. It is not I as cognitive inquirer confronting a situation; the situation surrounds and includes me.

Dewey was influenced by Peirce in his thinking that, in the process of coping with a problematic situation, we use not only ideas but also tools - physical ones like hammers with which we can physically reshape the environment, but also linguistic ones, which in communicative contexts may do just as well in reshaping the dynamics of the situation. ${ }^{5}$ For Dewey, ideas, as well as gestures and speech acts, are themselves tools for this kind of interaction. Furthermore, whether we are moving things about or reconstructing meaning, cognition is primarily a social event and is often accomplished in a joint effort. Cognition and such communicative processes are measurable in terms of their pragmatic success. A good idea consists of a set of practices that resolves the problem.

Dewey was thus criticizing a strict Cartesian division of labor between mind and body - a division of labor that was not simply theoretical and a problem for philosophers but that was finding its way into the pragmatics of everyday life. Consider the following description of management practices from Taylor's 1911 textbook Scientific Management:

Thus all of the planning which under the old system was done by the workman, as a result of his personal experience, must of necessity under the new system be done by the management in accordance with the laws of the science. . . It is also clear that in most cases one type of man is needed to plan ahead and an entirely different type to execute the work. The man in the planning room, whose specialty under scientific management is planning ahead, invariably finds that the work can be done better and more economically by a subdivision of the labour; each act of each mechanic, for example, should be preceded by various preparatory acts done by other men. (Taylor, 1911/1967, p. 37).

\footnotetext{
${ }^{5}$ David Kirsh (2004) summarizes Peirce's view that "thought is not just expressed in work, it is executed in work":
}

C.S Peirce, in his prescient way, was fond of saying that a chemist as much thinks with test tube and beaker as with his brain. His insight was that the activity of manipulating tools - in Peirce's case, manipulating representation rich tools and structures such as measuring devices, controllable flames, the lines in diagrams, written words - this activity is part of the overall process of thought. There is not the inner component, the true locus of thought, and its outer expression. The outer activity is a constituent of the thought process, though for Peirce it had to be continually re-interpreted to be meaningful. (Kirsh, 2004, p. 206) 
The separation of mental experience from hands-on physical manipulation of the environment was, for Dewey, both a philosophical and a social problem. ${ }^{6}$ For him, cognition is a form of action and not a relation between a thinking that goes on in the mind and a behavior that goes on in the world. The basic unit of experience is the organism-environment rather than a Cartesian cogito or Kantian pure ego:

We see that man is somewhat more than a neatly dovetailed psychical machine who may be taken as an isolated individual.... We know that his life is bound up with the life of society . .. we know that he is closely connected with all the past by the lines of education, tradition, and heredity.... We know that our mental life is not a syllogistic sorites, but an enthymeme most of whose members are suppressed; that large tracts never come into consciousness; that those which do get into consciousness, are vague and transitory, with a meaning hard to catch and read; ... that mind is no compartment box nor bureau of departmental powers. (Dewey, 1884, p. 278)

Dewey's concept of cognition is not far removed from what today is called "enactive cognition," which is the idea that perception and thinking are fully integrated with motor action. Yet one thing that Dewey clearly emphasizes and that is all but missing in some discussions of the enactive approach (e.g., Noë, 2004; Noë \& O'Regan, 2002; O'Regan \& Noë, 2001) is the fact that cognition is always socially situated. Throughout Noë's (2004) analysis of enactive perception, for example, we find elements like central nervous systems, sensory organs, skin, muscles, limbs, movements, actions, and plenty of physical and pragmatic situations to deal with. But there is no consideration given to the role that others (and our social or intersubjective interactions with them) play in the shaping of perceptual processes. For Noë (2004), "the key to [the enactive theory] is the idea that perception depends on the possession and exercise of a certain kind of practical knowledge" (p. 33). The mind is "shaped by a complicated hierarchy of practical skills" (p. 31). If we ask, How do we get this practical know-how? his answer is embodied practice and action. Dewey would not deny this, but he would certainly proffer the idea that we also get it from others - watching them act, communicating with them, and learning from them through processes like imitation, and indeed from the very start of life when we are completely dependent on others. ${ }^{7}$ What is important in this context is to recognize not simply that others populate our environment, or even that we interact with them and perceive their intentions, but that such interaction helps to shape our perception and understanding of things.

\footnotetext{
${ }^{6}$ We cannot help but be reminded of Marx's thoughts along this same line. He maintains that there is a close connection between consciousness, which is a social product, and labor - a connection that is ruined in alienated forms of labor (Marx, 1974; Marx \& Engels, 1964).

${ }^{7}$ In this regard, the work of Hurley (2006; this volume), who considers the importance of imitation, has a closer affinity to Dewey. Thompson and Varela (2001) also emphasize the importance of "cycles of intersubjective interaction, involving the recognition of the intentional meaning of actions and linguistic communication (in humans)" (p. 424). These authors never mention Dewey, however.
} 


\section{Being in the World}

Dewey's pragmatism acknowledges the importance of situation for the biological organism, and as such, his position is deep in the traditions of naturalism and psychologism. ${ }^{8}$ These views contend, for example, that the rules of logic are not absolute or independent of the biological or psychological makeup of the organism. One reaction to the relativism implied in such views is to make the Fregeian move to the logic of pure concepts and to understand conceptual meaning and truth to be independent of context. Another involves the Husserlian move to a transcendental consciousness that is distinct from the particularities of any individual's psychological constitution. Both moves are clearly away from the situatedness of experience and constitute a seeming retreat into a Cartesian, if not Platonic, mind. Heidegger recognized the ontological limitations of pursuing these lines of thought. In his questioning about the nature of the kind of entity that would be capable of such decontextualized thinking, he implies that human existence is specifically not that kind of entity. He finds an important clue to the nature of human existence and cognition in the notion of intentionality as it is developed in the work of Brentano and Husserl. Intentionality, the idea that all consciousness is consciousness of something or about something, signifies an unavoidable connection with the world. For Heidegger (1968), the kind of being that is capable of having an intentional relation to the world is a being that is already in the world in a more basic, ontological way. This is what he sets out to show in Being and Time, published in 1927.

From Heidegger's existential-phenomenological perspective, claims made by Dewey about the organism's embeddedness in the environment are claims informed by common sense (what Husserl called the "natural attitude") and natural science, and are thus made from an objective (external or observational) perspective. Heidegger's project is to dig deeper into a question that still has the ring of a certain kind of transcendentalism about it: what kind of existence does the human being have such that it is necessarily situated or embedded in the world? His response can be put into Dewey's language: ${ }^{9}$ the organism does not simply find itself deeply situated in an environment as one possibility rather than another. Rather, it is part of the very nature of human existence that being in the environment and being with others are necessary, existential characteristics. Dewey comes very close to saying precisely this:

The statement that individuals live in a world means, in the concrete, that they live in a series of situations. The meaning of the word "in" is different from its meaning when it is said that pennies are "in" a pocket or paint is "in" a can. It means . . that interaction is going on between individuals and objects and other persons. The conceptions of situation and of interaction are inseparable from each other. (Dewey, 1938b, p. 43)

\footnotetext{
${ }^{8}$ On Dewey's naturalism, see Santayana (1939).

${ }^{9}$ Notably, in the early 1930s, Dewey expressed interest in Heidegger's project, "particularly in his conception of the human situation" (Spiegelberg, 1976, p. 272).
} 
In Heidegger's words, Dasein (human existence) is in the world, not in the sense that we are simply geographically placed in the environment, but in the sense that a meaningful world constitutes part of our existence. To be situated, for Heidegger, is not simply something that happens to the human being, but it is part of the beingstructure of being human, and as such permeates every aspect of our cognitive and pragmatic activities and our social relations.

The world, in this sense, is not a collection of objects to be observed or contemplated by the mind. Rather, in a primary way, we have our hands in it. The world is "at hand" in an almost-literal sense (Heidegger uses the term Zuhandensein - being-to-hand). Things are not only available for our manipulation - we find ourselves already immersed in such manipulations or dealings, and the possibilities of such dealings shape our perceptions and actions. "The kind of dealing which is closest to us is . . . not a bare perceptual cognition, but rather that kind of concern which manipulates things and puts them to use; and this has its own kind of 'knowledge"' (Heidegger, 1968, p. 95). If, for example, I walk into my office, my primary relation to this setting is not as a collection of objects - desk, chairs, bookcases, computer, and so on, I do not think about the office door - I open it. I do not contemplate my desk or chair, I sit, absentmindedly, and start to work, with my attention on a problem to solve or a piece of correspondence to write. To use Gibson's term, the affordances offered by door, desk, chair, computer, and so on, are implicit in the way that I interact with them - they are ready-to-hand, as Heidegger (1968) says:

The kind of Being which belongs to these entities is readiness-to-hand. But this characteristic is not to be understood as merely a way of [perceptually or cognitively] taking them, as if we were talking such 'aspects' into the 'entities' which we proximally encounter. (p. 101)

That is, in the majority of our everyday dealings, we do not first encounter objects cognitively, and then decide what they are and what they can be used for. Cognition is "a founded mode" of Being-in-the-world that depends on our primary, pragmatic interaction with things (Heidegger 1968, p. 86). By the time we think about things, or explicitly perceive them as what they are, we have already been immersed in their pragmatic meaning.

To be pragmatically immersed in worldly contexts is to have a certain knowing relation to the world, which Heidegger calls "circumspection" (Umsicht) and distinguishes from theoretical knowledge. The latter takes things in the world as mere objects that we encounter in an observer mode (Heidegger refers to such objects as having a Vorhanden [present-to-hand] mode of being):

"Practical" behaviour is not "atheoretical" in the sense of "sightlessness." The way it differs from theoretical behaviour does not lie simply in the fact that in theoretical behaviour one observes, while in practical behaviour one acts, and that action must employ theoretical cognition if it is not to remain blind; for the fact that observation is a kind of concern is just as primordial as the fact that action has its own kind of sight. Theoretical behaviour is just looking, without circumspection. (Heidegger, 1968, p. 99) 
Heidegger points out that Cartesian philosophy and philosophical conceptions of science tend to overlook this basic ontological situatedness of the cognitive agent. ${ }^{10}$ Science begins as something that is already a cognitive, theoretical project. Nature "itself can be discovered and defined simply in its pure presence-at-hand. But when this happens, the Nature which 'stirs and strives', which assails us and enthralls us as landscape, remains hidden" (1968, p. 100). Heidegger claims that something poetic that is tied to our situatedness is lost in the third-person objective observations of science. Of course it is important to point out that even our most theoretical contemplations are situated as well, and it is questionable whether it is ever possible to capture something in its pure presence-at-hand. Theoretical behavior is never just looking without circumspection, even if it is sometimes conceived as such.

Heidegger's analysis raises important questions about the very nature of the situatedness of cognition as we try to understand it in the varied contexts of education, psychiatry, artificial intelligence, and so on. Can situatedness be properly characterized in third-person accounts, or does it require an existential analysis of the sort provided by Heidegger? In this sort of analysis, we catch sight of what it means to be situated in an environment, what readiness-to-hand itself means, primarily when readiness-to-hand breaks down - for example, when something we intend to use is discovered to be unusable, or when something we need is missing, or when something we need to get around stands obstinately in the way. In such cases, things are no longer there ready-to-hand, and just in that instance we catch sight of the very situatedness that normally characterizes our existence. In such instances, we do not escape being situated; rather, the situation simply shifts around us as different things become ready-to-hand for purposes of addressing the problem. But in this process the situation of always being in a situation announces itself and tells us something not simply about the world (or what Heidegger calls the "worldhood of the world") but about our own existence (i.e., that we are always situated, that we are in the world in such a radical way that we are never able to step outside of it). One can never get a "view from nowhere," as Nagel (1986) puts it. The situated view (which in other terms Heidegger calls the "hermeneutic situation") is something that qualifies all theoretical knowledge and all third-person scientific accounts. Moreover, being situated is something that in its inconspicuousness tends to escape our attention, but not simply because we overlook it, in the way that we might overlook something in the environment. Rather, it is part of what it means to be situated that the fact of being situated commonly goes unnoticed.

This inconspicuousness of being situated leads Heidegger to a number of interesting existential observations, for example, the idea that we are thrown into the world, that our familiarity and fascination with the world generally leads to our being lost to ourselves, a form of inauthenticity. To the extent that being situated commonly goes unnoticed, our sense of our own existence is curiously incomplete and likely misguided - something that gets cashed out in terms of the problems

\footnotetext{
${ }^{10}$ For an extended discussion of Heidegger in contrast to Cartesian psychology, see Wheeler (2005).
} 
encountered by classical cognitive science and strong artificial intelligence (see Wheeler, 2005). At the same time, such incompleteness is part of what our existence means and is tied to the finitude of our understanding. Heidegger also suggests some caution about any philosophy of the world that starts with an understanding of the world as a res extensa - Descartes' notion of an extended, spatial thing - or any philosophy of mind that starts with an understanding of the mind as a res cogitans, the idea that the mind is a substance or thing that thinks. What the Cartesian ontology overlooks is exactly the kind of situatedness that Heidegger describes. For Descartes, a thing (whether extended or thinking) is a substance, which, Heidegger explains, is a form of being that is present at hand and precisely not that form of being through which we are always situated (the ready-to-hand). Indeed, for Descartes, as for metaphysics generally and for natural science, the kind of being attributed to things, including the entity of the human being, is the kind of being that we access in an explicit (third-person) observational attitude and the kind of being that is open to analysis by cognition, "intellectio in the sense of the kind of knowledge we get in mathematics and physics" (Heidegger, 1968, p. 128). Heidegger's existential analysis is meant to show that human existence is precisely not something present-at-hand, an object among other objects, but is in-the-world, that is, always situated in a way that the world is primarily ready-to-hand.

Within our everyday situated projects, we also encounter entities with a being that is different from the things that are simply ready-to-hand. These are other humans, that is, other entities who are in-the-world in the way that we are in-theworld. For Heidegger, others appear within the pragmatic contexts that characterize our life. Along with the activities that we are engaged in, "We encounter not only entities ready-to-hand but also entities with Dasein's kind of Being - entities for which, in their concern, the product [e.g., that we may be engaged in producing] becomes ready-to-hand" (1968, p. 100). Likely as not, our own activities often require others to play some role. I am never an isolated I without others (1968, pp. 147-163). Moreover, I do not encounter others primarily as those who are in opposition to me but as those from whom I do not distinguish myself. That is, in regard to other persons, I do not first or in a primary way encounter strangers; rather, I find myself already included with others. According to Heidegger, this with is to be understood as part of the very structure of human existence. That is, being-in-theworld already includes being-with; being situated already involves being situated with others. $^{11}$

Heidegger also presents an analysis of spatiality that is tied to our situated condition. Space is objective only derivatively; it is first of all related to the kinds of activities in which we are engaged. Thus, "a pathway which is long 'Objectively' can

\footnotetext{
${ }^{11}$ Heidegger points out that this is the case even if one is alone. The claim that our existence is characterized as being-with "must be understood as an existential statement as to its essence. Even if the particular factical Dasein does not turn to Others, and supposes that it has no need of them or manages to get along without them, it is in the way of Being-with" (1968, p. 160).
} 
be much shorter than one which is 'Objectively' shorter still but which is perhaps 'hard going' and comes before us as interminably long' (1968, p. 141). Far and close are determined by our pragmatic relations. Five miles is a long distance to go to buy a newspaper but not so long if you intend to purchase a new home. Far and close also become metaphors that inform our evaluation of situations. I may feel closer to a person who lives a thousand miles away than to the person standing next to me (1968, p. 141).

Heidegger's discussion of embodiment is minimal and is found mostly in the context of his analysis of spatiality. Closeness, he maintains, is not definable as an objective distance from one's body. Even the "here" is not defined in terms of bodily location, but relative to a "there" that is defined pragmatically. How do I reach the thing that is there; how do I move myself over there? Only in relation to such concerns do I start to consider my "here." In this sense, in my situation, I am always "there," or at least directed to the "there," and in that light my "here" is defined as too far (from the "there" where I need to be), or too awkwardly positioned, and so on. Heidegger even suggests that right and left emerge in such pragmatic relations, and that our spatialization "in its 'bodily nature' is likewise marked out in accordance with these directions" (1968, p. 143). According to Heidegger, however, our embodied sense of right and left play no role in these determinations.

Heidegger's accounts of both intersubjectivity and spatiality remain closely tied to his analysis of the pragmatic or instrumental situation. Our encounters with others are always situated in pragmatic contexts - he often uses the example of workrelated projects. As such, we encounter others not directly but across our dealings with things. Others "show themselves in the world in their special environmental Being, and do so in terms of what is ready-to-hand in that world" (1968, p. 160). That is, others appear as engaged in pragmatic contexts similar to (or different from) our own. This analysis leaves little room for more direct and personal relations such as those based on emotional or even biological attraction. Without doubt, such personal relations may also be situated in instrumental contexts, but it is also possible to find such relations in what are closer to purely social or communicative contexts. Likewise, spatiality is cast in purely instrumental terms with little role for embodied processes. Heidegger does not deny that our existence is embodied, but he does not say very much about it.

\section{Embodiment and Beyond}

Merleau-Ponty, working in the same phenomenological tradition, takes both embodiment and intersubjectivity as more central to the way that experience works. His anti-Cartesian view of the active body derives from his study of Bergson and what were Husserl's unpublished manuscripts (especially Husserl, 1952). Husserl had outlined a concept of embodiment that distinguished Descartes' concept of the objective body (the body as an object extended in space, or as studied by biological science) and the lived body (Leib), which is the body that I experience and with 
which I act. It is the lived body that gears into the affordances of the world, and that, according to Husserl, is lived as an "I can." I approach the world with all of the possibilities for movement and action that are of my body. I experience the world in an egocentric spatial framework that is determined by my body. In this regard, "my body appears to me as an attitude directed towards a certain existing or possible task. And indeed its spatiality is not, like that of external objects or like that of 'spatial sensations', a spatiality of position, but a spatiality of situation" (Merleau-Ponty, 1962, p. 100).

Bergson, too, had provided a rich concept of embodied cognition. In Matter and Memory (1911), he understands memory to accumulate in the body as a set of responses to a complex set of solicitations from the world. The body retains

[...] from the past only the intelligently co-ordinated movements which represent the accumulated efforts of the past; and it recovers those past efforts, not in the memory-images which recall them, but in the definite order and systematic character with which the actual movements take place. In truth, it no longer represents our pasts to us, it acts it; and if it still deserves the name memory, it is not because it conserves bygone images, but because it prolongs their useful effect into the present moment. (Bergson, 1911, p. 93)

Merleau-Ponty supplements these philosophical sources with his own study of psychology and neurology. He borrows the concept of body schema from Head and Holmes (1911-1912). Consistent with Bergson's concept of embodied memory, Head's (1920) body schema dynamically organizes sensorimotor feedback in such a way that the final sensation of position is "charged with a relation to something that has happened before" (p. 606). Head uses the metaphor of a taximeter, which computes and registers movement as it goes. Merleau-Ponty relates this metaphor to Husserl's analysis of time-consciousness, which shows that we should think of experience not as momentary but as a temporally extended yet cohesive flow structured to enable retentions (of the just past) and protentions (of the just about to be). For Merleau-Ponty (1968), action is also temporally extended and organized according to the "time of the body, taximeter time of the corporeal schema" (p. 173). And this includes a retentional component, as well as anticipatory aspects: "At each successive instant of a movement, the preceding instant is not lost sight of. It is, as it were, dovetailed into the present. ... [Movement draws] together, on the basis of one's present position, the succession of previous positions, which envelop each other" (Merleau-Ponty, 1962, p. 140).

This temporality is essential to the structure of our situated experiences and actions. We are situated not only spatially but also in time, and more generally in history. Indeed, Merleau-Ponty suggests that the experience of meaning or our ability to make sense of things within the space of the environment is only possible if our experience is structured in this temporal (retentional-protentional) way. Imagine if every experience we had completely fell away into a past that remained inaccessible to us. If our perception or thought were a strictly synchronic experience, there could be no meaningful structure to it; it would lack context and connection with anything else that we experience. But, Merleau-Ponty warns, we should not think that the 
problem is solved on a purely physiological or purely psychological level. That is, as Bergson had shown, the temporality of experience that is a necessary condition for us to be in a situation is not explainable as a physical trace within an objective body or brain, as such traces would be purely present and not sufficient to explain the past. But, Merleau-Ponty suggests, for the same reason neither is some unconscious or psychical trace sufficient. A present representation of the past or any present content of consciousness remains present; it cannot explain why we might take it as representing the past. Rather, he proposes that we have a direct but incompletely constituted "contact with the past in its own domain" (1962, p. 413), but not in the form of an object of knowledge. Temporality is in some way a "dimension of our being" (p. 415). More specifically, it is a dimension of our situated existence. Merleau-Ponty explains this along the lines of the Heideggerian analysis of being-inthe-world. It is in my everyday dealings with things that the horizon of the day gets defined: it is in "this moment I spend working, with, behind it, the horizon of the day that has elapsed, and in front of it, the evening and night - that I make contact with time, and learn to know its course" (pp. 415-416). It is not that I represent the day as measurable by the clock;

I do not form a mental picture of my day, it weighs upon me with all its weight, it is still there, and though I may not recall any detail of it, I have the impending power to do so, I still 'have it in hand.' . . . Our future is not made up exclusively of guesswork and daydreams. Ahead of what I see and perceive ... my world is carried forward by lines of intentionality which trace out in advance at least the style of what is to come. (1962, p. 416)

Thus, Merleau-Ponty suggests, I feel time on my shoulders and in my fatigued muscles; I get physically tired from my work; I see how much more I have to do. Time is measured out first of all in my embodied actions as I "reckon with an environment" in which "I seek support in my tools, and am at my task rather than confronting it" (p. 416). Accordingly, my sense of time emerges out of my situated actions: "What, in fact, do we mean when we say that there is no world without a being in the world? Not indeed that the world is constituted by consciousness, but on the contrary that consciousness always finds itself already at work in the world" ( $p$. 432).

What finds itself already at work in the world is not the Cartesian cogito, which, Merleau-Ponty suggests, thought has to strain to discover. Rather, "my body, in a familiar surrounding, finds its orientation and makes its way among objects without my needing to have them expressly in mind" (1962, p. 369). It is not a matter of an "I" standing back as an observer of the things around me; "rather it is that my consciousness takes flight from itself and, in them, is unaware of itself" (p. 369), and it does this in perception as in action. Merleau-Ponty means that there is no explicit or conceptual or reflective awareness of myself, or of my body, when I am engaged in my everyday projects. It is not that, as if by some inner power, I conceive of a space through which I need to guide my hand as it reaches to grasp something; the shape of my grasp is not a representation of the object that I intend to grasp. How could anything like this be possible, Merleau-Ponty asks, if my hand was "not 
already situated on a path" of action (p. 370)? The situation, then, is not laid out before me, as an object of consciousness; it is a tergo - I am in it and it is affecting me before I know it. Merleau-Ponty brings this affectivity into focus as an important component of situated cognition in a way that the theorists of enactive perception sometimes lose sight of.

In agreement with such theorists, Merleau-Ponty would say that vision or, more generally, perception is a form of action (1962, p. 377). ${ }^{12}$ Merleau-Ponty, however, would balance this claim with the idea that the world, the situation we find ourselves in, also shapes our vision, and there is an element of passivity, or more properly affectivity, that is built into our way of being in the world. Moreover, this is not simply the case for perception but extends to the full cognitive-emotionallinguistic life of an individual and can easily have a normative significance:

Children and many grown people are under the sway of 'situational values', which conceal from them their actual feelings - they are pleased because they have been given a present, sad because they are at a funeral, gay or sad according to the countryside around them, and, on the hither side of any such emotions, indifferent and neutral. . . Our natural attitude is not to experience our own feelings or to adhere to our own pleasures, but to live in accordance with the emotional categories of the environment. (1962, pp. 379-380)

This kind of affectivity is obviously involved in intersubjectivity, which Merleau-Ponty analyzes in terms of what he calls "intercorporeality." Although Merleau-Ponty acknowledges the kind of analysis that Heidegger provided (i.e., that we encounter others across the various instrumental contexts involved in everyday life; see Merleau-Ponty, 1962, pp. 347-348), this is not a sufficient account because it does not answer precisely how we come to recognize them, in the first place, as other persons rather than as, for example, other, albeit peculiar, instruments, or how we escape a kind of philosophical autism. Rather, one needs to understand this problem in terms of embodiment and to recognize that "the very first of all cultural objects, and the one by which all the rest exist, is the body of the other person as the vehicle of a form of behavior" (1962, p. 348). My access to the other is not by way of inference or analogy, using the other's body as a means to project myself into his or her mind. Rather, there is a direct interrelation between my body and the other's body

\footnotetext{
${ }^{12}$ See Noë $(2004$, pp. 1, 73), who cites Merleau-Ponty in this context: "You aren't given the visual world all at once. You are in the world, and through skillful visual probing - what Merleau-Ponty called 'palpatation with the eyes' - you bring yourself into contact with it. . . . Like touch, vision is active" (Noë, 2004, p. 73). The idea of enactive perception recently put forward by Varela, Thompson, and Rosch (1991), Hurley (1999), O’Regan and Noë (2001), and others, often with references to Merleau-Ponty, has been discussed at least since the end of the nineteenth century. Noë could just as easily have cited Dewey's statement from his 1896 essay "The Reflex Arc Concept in Psychology”:
}

not with a sensory stimulus, but with a sensori-motor coordination . . . it is the movement which is primary, and the sensation which is secondary, the movement of body, head and eye muscles determining the quality of what is experienced. . . [In audition] the sound is not a mere stimulus, or mere sensation; it again is an act. . . . It is just as true to say that the sensation of sound arises from a motor response as that the running away is a response to the sound. (p. 358) 
at the level of perception (see Gallagher, 2001, 2005, chap. 9). Merleau-Ponty suggests what developmental psychology has only recently shown; namely, even young infants are capable of perceiving the intentions of others $(1962$, p. 352; see, e.g., Baldwin \& Baird, 2001; Baldwin, Baird, Saylor, \& Clark, 2001; Meltzoff, 1995). But, more than this, there is a direct resonance between my bodily behavior and the bodily behavior of the other.

This concept of intercorporeality finds good support in recent research on mirror neurons and neuronal resonance systems (e.g., Decety \& Sommerville, 2003; Jeannerod, 2001; Rizzolatti, Fadiga, Gallese, \& Fogassi, 1996; Rizzolatti, Fadiga, Matelli, et al., 1996), although these phenomena would not have led Merleau-Ponty in the direction of simulation theory, as we find in many authors (e.g., Gallese \& Goldman, 1998; Jeannerod \& Pacherie, 2004). If by simulation one means the use of a model to understand something that cannot be understood directly (e.g., the other's mind), a routine in which I manipulate a set of first-person as-if intentions - and this is the concept of simulation as it is defined by simulation theory - then this is clearly not what is going on in the activation of mirror neurons. The activation of resonance systems is automatic and subpersonal; that is, it is not I who do it but rather a process in the perceiver's brain that is elicited by the perception of the other's action. It is not something the subject decides to do, or does actively, and therefore it is not a simulation in that sense. If activation of the mirror system looks like a first-person pretense, it does so only to an external observer, not to the subject or system itself. Neurons do not fire as if they were generating action; they just fire. ${ }^{13}$ If intercorporeality is about action, it is not entirely about my action in response to others but must include the effect that the other's action has on my system. It is not that I simulate the action of the other; it is rather that the other's action elicits the resonant responses in my system. In this affectivity we find ourselves pulled into a situation that is already intersubjective. Just as Merleau-Ponty (1962) suggests that "the theory of the body is already a theory of perception" (p. 203), we could suggest that the theory of the body is already a theory of intersubjectivity.

A similar affectivity can be found in language, which in some sense may be a tool that we use for communicative action with others - "I learn [language] as I learn to use a tool, by seeing it used in the context of a certain situation" (Merleau-Ponty, 1962 , p. 403) - but in another sense is not something that we totally control in our speech acts; rather, it is something that contributes to the constitution of the situation in which we find ourselves immersed. Thus,

language takes on a meaning for the child when it establishes a situation for him. . . . The power possessed by language of bringing the thing expressed into existence, of opening up to thought new ways, new dimensions and new landscapes, is, in the last analysis, as obscure for the adult as for the child. (Merleau-Ponty, 1962, p. 401)

\footnotetext{
${ }^{13}$ See Gallagher (2007) for a critique of implicit simulation theory. I thank Philip Robbins for alerting me to an article by Goldman and Sripada (2005). They define a minimal sense of simulation that does not involve subjective control or the generation of pretend states. How a minimal concept of simulation differs from perception on an enactive model is not clear, however.
} 
For Merleau-Ponty, language has this effect on us; in the speech act, the subject does not first represent the words to him- or herself; the subject "plunges into speech," and in so doing "reveals a motor presence of the word which is not the knowledge of the word" (1962, p. 403). My speech involves both my action and a passive affectivity: it is "a certain use made of my phonatory equipment, a certain modulation of my body as a being in the world" (1962, p. 403) that is simultaneously and ambiguously my action and something that language does to me.

\section{Language in the Context of Everyday Life}

It is also the case that language use is a socially constrained practice. According to Wittgenstein (1953), our use of language is similar to playing a game that has a particular set of rules. Each use of language, however, involves a different language game, where the various games are run according to different sets of rules, and there are no universal rules. The games are played, we might say, in the world, and linguistic meaning is determined by the circumstances in which any particular game is played. On this view, a private language - a language spoken by a person who somehow grasps a conceptual truth about the world and then simply expresses that truth in words that receive their meaning from what goes on in his or her isolated mind - is not intelligible to, or learnable by, anyone other than the speaker, because a language consists of a communicative system that exists only between agents who are in social interaction. Linguistic meaning is generated in that kind of contextualized communication:

Language games are the forms of language with which a child begins to make use of words. .

.. When we look at the simple forms of language the mental mist which seems to enshroud our ordinary use of language disappears. We see activities, reactions, which are clear-cut and transparent. (Wittgenstein, 1969, p. 17)

Language is grounded on acting in particular contexts, and in the immediate reactions we have to others. The meanings of words are not the products of the linguistic system nor derived from a one-to-one correspondence to items in the world; rather, they are generated in the activities in which they are used. In this sense the use of a term does not presuppose having a concept stored in one's head. Rather, language is generated in the experience of the various contexts, practices, and activities that generate meaning. I do not think first in abstraction and then put a word to the concept (see, e.g., Gauker, 2003, 2005; Travis, 1989). There are no abstract principles or universal rules that would allow me to do that. I am first involved in some project in a specific setting - for example, a science lab, an operating room, an airport - and in a specific kind of discourse or conceptual practice that others share just in such settings, in the same way that they share certain instruments and technologies.

Wittgenstein is thus committed to some form of externalism, the idea that the meaning of a word or statement depends on the linguistic community in which the word is used and/or depends on what exists or happens in the environment (for a 
discussion, see Overgaard, 2004). To know what something means is not equivalent to simply being in a certain psychological state (Putnam, 1975). Following a rule in a language game does not involve a metacognitive interpretation of a rule that we somehow hold in our head. It is rather an ability that consists in nothing more or less than a practice, the mastery of which has been fined tuned in particular settings (Wittgenstein, 1953, § 201). If the notion of situated cognition emphasizes the contextual dimensions of such practices, where the meaning of a concept, and the significance of verbal and gestural actions are inseparable from the setting of action, or from a form of life, then Wittgenstein is clearly describing situated cognition. In a well-defined situation, a practice can be well defined not by the existence of a rule book that is consulted, or by an explicit understanding of the rules, but by the physical and socially defined situation itself. The meaning of a concept is not fixed or universal, as it is dependent on its use in specific contexts, which are subject to temporal and historical change. What determines our concepts, Wittgenstein asserts, is "the whole hurly-burly of human actions, the background against which we see any action" (1967, § 567).

Wittgenstein (1953, §§ 2-21) describes the practices of a builder and his assistant cooperating on a project in which meanings are created by ostensive reference precisely because the context is narrowly circumscribed so as to define a shared communicative situation. The tasks that compose this project are context specific and require skills that are not only about material construction but also about conceptual construction. A language and a set of concepts are created by the particular purposes involved in the situation. The vocabulary involved in this context consists of four words - block, pillar, slab, beam - names of the four items that the builders use to build. Grammatically, the utterance of one word is, in this context, a sentence. Moreover, when the builder utters the word slab, something gets accomplished - the assistant passes on a slab. Thus, in contrast to traditional approaches that make concept use a matter of detached and deliberative judgment, Wittgenstein maintains that concept use is more like a practical skill.

Proponents of situated cognition have argued both for and against the idea that this kind of skill is nonrepresentational, an issue that is taken up in other chapters of this volume. ${ }^{14}$ Here it may be helpful to mention how Wittgenstein fits into this debate. A radical situationist can argue that because we are already in the world, we do not need to replicate the world in our head; an internal representation would be no better than the access we have to the world itself (see, e.g., Noë, 2004, p. 219). That is, we do not need a representation of the world if, in fact, the world is there for our having. When the builder says "slab," the assistant does not need to form a mental

\footnotetext{
${ }^{14}$ See chapters in this volume by Adams and Aizawa, Clark, Eliasmith, Millikan, and Rowlands. See also Anderson (2003); Brooks (1999); Clancey (1997); Hutto (in press); Kirsh (2004); Noë (2004), Rowlands (2007), and the special issue of Phenomenology and the Cognitive Sciences (vol. 1, no. 4, 2002) on Dreyfus's anti-representationalism.
} 
image of a slab; the slab is perceptually and handily available. ${ }^{15}$ His concept of slab its meaning - is equivalent to what he can do with it. At the very least we can say that a representation in the form of a mental image is not necessary for the successful use of language. Rowlands (2007), however, argues that the Wittgensteinian appeal to practice, understood as a form of intentional action, is not sufficient to rid cognitive systems of representations.

Wittgenstein, famously, developed a paradox concerning the possibility of rule following. Many commentators have thought that the key to solving this paradox lies in Wittgenstein's (1953) appeal to practice: "And hence also 'obeying a rule' is a practice. And to think one is obeying a rule is not to obey a rule. Hence it is not possible to obey a rule 'privately': otherwise thinking one was obeying a rule would be the same thing as obeying" (\$202; see also Rowlands, 2007)

That is, in our ordinary practice in everyday contexts, we do not explicitly consult a set of rules to guide our practice; indeed, consulting the rules would itself be a practice different from the worldly practice that we are trying to guide. But Rowlands argues that the appeal to practice cannot explain away representations because, at least in the traditional view, practice involves intentional action, and this presupposes some form of representational content. "A practice is what we do. However, doing, it seems, is a form of acting and, as such, is essentially connected to intentional states. But intentional states are individuated by their content. . . . And content arises through representation" (Rowlands, 2007). To defeat representationalism once and for all, Rowlands argues, one needs a different concept of action than the one Wittgenstein was working with. ${ }^{16}$

It is not clear, however, that Wittgenstein was working with one concept of action or one concept of representation. It would seem to be a Wittgensteinian principle that there is no one correct answer to the question of whether a representational concept of skill, or action, or mind is better than a nonrepresentational one. In the cognitive sciences, for example, there are in fact many different meanings to the term representation (sometimes the term is used in discussing mental images, sometimes in discussing reference, and other times in describing neuronal firing patterns), and whether we are willing to accept the implications carried by the term may depend on the particular theoretical context in which it is used. Likewise, in regard to the question of everyday practice, it may be the case that some practices are representational and some are not, depending on how the term might be descriptive of the different pragmatic contexts. The argument between representationalists and nonrepresentationalists, the Wittgensteinian might suggest, is complicated by the use of multiple language games that differ from one discourse to another, from phenomenology and philosophy to psychology and the

\footnotetext{
${ }^{15}$ This may run against situated approaches to language comprehension and concept use that emphasize the role of simulation. For discussion, see chapters in this volume by Zwaan and Kaschak, and by Barsalou.

${ }^{16}$ For a discussion of content and practice in Wittgenstein, see Hurley (1999, Chap. 6).
} 
cognitive neurosciences. The term representation does not have a meaning outside of its particular uses in these different language games. Is it better to use the word representation than to not use it? Better for what? Assuming that in certain contexts we agree on the concepts of intentional state and intentional content, Rowlands's insistence on the notion of representation may be correct for those contexts.

This brings us to the possibility that theories of situated cognition are themselves differently situated, within different disciplines or discourses, shaped by specific debates and specialized vocabularies. In any case, it is generally understood that Wittgenstein offers significant resources in support of the notion of situated cognition and against both Cartesian dualist metaphysics and the more recent computationalist views. ${ }^{17}$ For Wittgenstein, cognition cannot be reduced to propositional knowledge tightly organized in a well-formed mind; cognition is really a collection of skills and practices that rely on commonsense know-how and contextspecific knowledge. The contexts of cognitive practices are also always social, so that what we call our beliefs have meaning only in virtue of their role in the social contexts in which we participate (see, e.g., Brandom, 1994).

\section{Conclusion}

Dewey, Heidegger, Merleau-Ponty, and Wittgenstein provide continuing resources for approaches to cognition that recognize its situated nature. I have suggested that these thinkers are not just part of the historical background, but that we can learn by thinking further about their contributions. They remind us that cognition is not only pragmatically situated but also always socially situated, not simply in the sense that the world is populated with others with whom we communicate but also in the sense that this communication and interaction shape our cognitive abilities from the very beginning. They push us to realize that cognition not only is enactive but also elicited by our physical and social environment; that it not only involves a deeply embodied and temporally structured action but also is formed in an affective resonance generated by our surroundings and by others with whom we interact. These thinkers also challenge us to consider what it means to think of cognition as situated, what it means to do a science of situated cognition, and what it means if we end up with more than one conception of what situated cognition means.

\footnotetext{
${ }^{17}$ Even if some philosophers still think that Turing wins out over Wittgenstein, current theorists of artificial intelligence and robotics are not so sure. Dennett (2003, p. 3) writes: "What Turing saw, and Wittgenstein did not, was the importance of the fact that a computer doesn't need to understand rules to follow them. Who "won"? Turing comes off as somewhat flatfooted and naive, but he left us the computer, while Wittgenstein left us . . Wittgenstein.” Rodney Brooks (1999), in his work on robotics, clearly takes Turing's gift but works with it in a Wittgensteinian situated framework.
} 


\section{References}

Anderson, M. L. (2003). Embodied cognition: A field guide. Artificial Intelligence, 149, 91-130.

Baldwin, D. A., \& Baird, J. A. (2001). Discerning intentions in dynamic human action. Trends in Cognitive Sciences, 5, 171-78.

Baldwin, D. A., Baird, J. A., Saylor, M. M., \& Clark, M. A. (2001). Infants parse dynamic action. Child Development, 72, 708-717.

Bergson, H. (1911). Matter and memory (N. M. Paul \& W. S. Palmer, Trans.). London: George Allen \& Unwin.

Brandom, R. (1994). Making it explicit: Reasoning, representing, and discursive commitment. Cambridge, MA: Harvard University Press.

Bredo, E. (1994). Reconstructing educational psychology: Situated cognition and Deweyan pragmatism. Educational Psychologist, 29, 23-35.

Brooks, R. (1999). Cambrian intelligence: The early history of the new AI. Cambridge, MA: MIT Press.

Brown, J. S., Collins, A., \& Duguid, P. (1989). Situated cognition and the culture of learning. Educational Researcher, 18, 32-42.

Clancey, W. J. (1997). Situated cognition: On human knowledge and computer representation. Cambridge: Cambridge University Press.

Clark, A. (1997). Being there: Putting brain, body, and world together again. Cambridge, MA: MIT Press.

Decety, J., \& Sommerville, J. A. (2003). Shared representations between self and other: A social cognitive neuroscience view. Trends in Cognitive Sciences, 7(12), 527-533.

Dennett, D. (2003). Ludwig Wittgenstein. The Time 100. Retrieved from http://www.time.com/time/time100/scientist/profile/wittgenstein.html (retrieved 9 May 2008)

Dewey, J. (1884). The new psychology. Andover Review, 2, 278-289. Retrieved from http://psychclassics.yorku.ca/Dewey/newpsych.htm (retrieved 9 May 2008)

Dewey, J. (1896). The reflex arc concept in psychology. Psychological Review, 3, 357-370. Retrieved from http://psychclassics.yorku.ca/Dewey/reflex.htm (retrieved 9 May 2008)

Dewey, J. (1938a). Logic: The theory of inquiry. New York: Holt, Rinehart \& Winston.

Dewey, J. (1938b). Experience and education. New York: Macmillan.

Gallagher, S. (2001). The practice of mind. Journal of Consciousness Studies, 8(5-7), 83-107.

Gallagher, S. (2005). How the body shapes the mind. Oxford: Oxford University Press.

Gallagher, S. (2007). Logical and phenomenological arguments against simulation theory. In D. Hutto \& M. Ratcliffe (Eds.), Minding our practice: Folk psychology re-assessed (63-78). Dordrecht, Netherlands: Springer.

Gallese, V. L., \& Goldman, A. (1998). Mirror neurons and the simulation theory of mind-reading. Trends in Cognitive Science, 2, 493-501.

Gauker, C. (2003). Words without meaning. Cambridge, MA: MIT Press.

Gauker, C. (2005). On the evidence for prelinguistic concepts. Theoria, 54, 287-297. 
Goldman, A. I., \& Sripada, C. S. (2005). Simulationist models of face-based emotion recognition. Cognition, 94, 193-213.

Head, H. (1920). Studies in neurology (Vol. 2). London: Oxford University Press.

Head, H., \& Holmes, G. (1911-1912). Sensory disturbances from cerebral lesions. Brain, 34, 102245.

Heidegger, M. (1968). Being and time (J. Macquarrie \& E. Robinson, Trans.). New York: Harper \& Row.

Hurley, S. (1999). Consciousness in action. Cambridge, MA: Harvard University Press.

Hurley, S. (2006). Active perception and perceiving action: The shared circuits hypothesis. In T. Gendler \& J. Hawthorne (Eds.), Perceptual experience (pp. 205-259). New York: Oxford University Press.

Husserl, E. (1952). Ideen zu einer reinen phänomenologie und phänomenologischen philosophie. Zweites Buch. M. Biemel (Ed.), Husserliana IV. The Hague: Martinus Nijhoff.

Hutto, D. (2005). Knowing what? Radical versus conservative enactivism. Phenomenology and the Cognitive Sciences, 4(4), 389-405

Jeannerod, M. (2001). Neural simulation of action: A unifying mechanism for motor cognition. NeuroImage, 14, 103-109.

Jeannerod, M., \& Pacherie, E. (2004). Agency, simulation, and self-identification. Mind and Language, 19(2), 113-146.

Johnson, M. (2007). The meaning of the body. Chicago: University of Chicago Press.

Kirsh, D. (2004). Metacognition, distributed cognition and visual design. In P. Gärdinfors \& P. Johansson (Eds.), Cognition, education and communication technology (147-180). Mahwah, NJ: Lawrence Erlbaum.

Lave, J. (1988). Cognition in practice: Mind, mathematics, and culture in everyday life. Cambridge: Cambridge University Press.

Lave, J., \& Wenger, E. (1991). Situated learning: Legitimate peripheral participation. Cambridge: Cambridge University Press.

Marx, K. (1974). Economic and philosophic manuscripts of 1844. Moscow: Progress.

Marx, K., \& Engels, F. (1964). The German ideology (S. Ryazanskaya, Trans.). Moscow: Progress.

Meltzoff, A. N. (1995). Understanding the intentions of others: Re-enactment of intended acts by 18month-old children. Developmental Psychology, 31, 838-850.

Merleau-Ponty, M. (1962). Phenomenology of perception (C. Smith, Trans.). London: Routledge \& Kegan Paul.

Merleau-Ponty, M. (1968). The visible and the invisible (A. Lingis, Trans.). Evanston, IL: Northwestern University Press.

Nagel, T. (1986). The view from nowhere. Oxford: Oxford University Press.

Nietzsche, F. W. (1967). The will to power (R. Hollingdale \& W. Kaufmann, Trans.). London: Random House.

Noë, A. (2004). Action in perception. Cambridge, MA: MIT Press.

Noë, A., \& O'Regan, J. K. (2002). On the brain basis of perceptual consciousness. In A. Noë \& E. Thompson (Eds.), Vision and mind: Selected readings in the philosophy of perception (pp. 567-598). Cambridge, MA: MIT Press. 
O’Regan, J. K., \& Noë, A. (2001). A sensorimotor approach to vision and visual consciousness. Behavioral and Brain Sciences, 24(5), 939-973.

Overgaard, S. (2004). The private language argument and externalism. Danish Yearbook of Philosophy, 39, 17-48.

Putnam, H. (1975). Mind, language, and reality: Philosophical papers (Vol. 2). Cambridge: Cambridge University Press.

Rizzolatti, G., Fadiga, L., Gallese V., \& Fogassi, L. (1996). Premotor cortex and the recognition of motor actions. Cognitive Brain Research, 3, 131-141.

Rizzolatti, G., Fadiga, L., Matelli, M., Bettinardi, V., Paulesu, E., Perani, D., \& Fazio, G. (1996). Localization of grasp representations in humans by PET: 1. Observation compared with imagination. Experimental Brain Research, 111, 246-252.

Rowlands, M. (2007). Understanding the 'active' in 'enactive.' Phenomenology and the Cognitive Sciences, 6(4), 427-443.

Santayana, G. (1939). Dewey's naturalistic metaphysics. In P. A. Schilpp (Ed.), The philosophy of John Dewey (pp. 245-261). Evanston, IL: Northwestern University Press.

Spiegelberg, H. (1976). The phenomenological tradition. The Hague: Martinus Nijhoff.

Taylor, F. W. (1967) The principles of scientific management. New York: Harper \& Brothers, W. W. Norton \& Company. (Original work published 1911)

Thompson, E., \& Varela, F. (2001). Radical embodiment: Neural dynamics and consciousness. Trends in Cognitive Sciences, 5(10), 418-425.

Travis, C. (1989). The uses of sense: Wittgenstein's philosophy of language. Oxford, UK: Clarendon.

Varela, F., Thompson, E., \& Rosch, E. (1991). The embodied mind. Cambridge, MA: MIT Press.

Wheeler, M. (2005). Reconstructing the cognitive world. Cambridge, MA: MIT Press.

Wittgenstein, L. (1953). Philosophical investigations (G. E. M. Anscombe, Trans.). Oxford, UK: Blackwell.

Wittgenstein, L. (1967). Zettel. Oxford, UK: Blackwell.

Wittgenstein, L. (1969). On certainty. New York: Harper Torchbooks. 